\title{
The Cognitive Style-Based Learning Strategy in Webbed Curriculum of Elementary School
}

\author{
Arif Sholahuddin \\ Faculty of Teacher Training and Education \\ Universitas Lambung Mangkurat \\ Banjarmasin, Indonesia \\ arif.science.edu@unlam.ac.id
}

\author{
Leny Yuanita, Z. A. Imam Supardi \\ Science Education Department Postgraduate Program \\ Universitas Negeri Surabaya \\ Surabaya, Indonesia
}

\begin{abstract}
The Cognitive Style-Based Learning Strategy (CSBLS) has developed and tried out in an elementary school classroom with Education Unit Level Curriculum 2006. Meanwhile, since 2013 Indonesia has been tried the new National Curriculum 2013 or called K-13. This paper aims to analyze the feasibility of that learning strategy to be applied in elementary school classroom using K-13. The analysis was conducted qualitatively by comparing the characteristics of webbed or integrated thematic curriculum, the forms of $K-13$ at the elementary school, with the characteristic of CSBLS. The characteristics of integrated thematic curriculum incorporate various disciplines to achieve cognitive, affective, and psychomotor competence. The suggested learning approach is the scientific approach, which involves four main skills namely observing, questioning, experimenting, associating, and networking/communicating. Various activities neither have to be trained sequentially nor performed all skills in a classroom meeting. CSBLS has the steps that are in line with a scientific approach. The steps are concise of giving attention, understanding, exploring, sharing, game, assessment, and individual tasks. Understanding the steps, training the skill of questioning, observing, associating, communicating data, sharing step trained a verbal communicating and individual tasks involve all skills which are undertaken independently by students. According to its characteristics, the CSBLS can be applied in K13 by a little adaptation. It only requires the change of learning materials from subject areas to themes as a learning content. The implementation of the CSBLS can facilitate individual differences especially related to elementary students' cognitive style and their tendency to prefer group activities.
\end{abstract}

Keywords-cognitive style, learning strategy, webbed curriculum

\section{INTRODUCTION}

The fundamental change of national curriculum from the Education Unit Level Curriculum or Competency-Based Curriculum to National Curriculum 2013 or K-13, has conducted by the Indonesian government. It was a strategic way to answer the demands of national education quality based on the national standard of education as well as global development challenge. This way is important for Indonesia because the productive age population will peak in 2020-2035 when it reaches $70 \%$ quantitatively [1] that require adequate preparation of knowledge, attitudes, and skills to face the global arena.
One of the international indicators for predicting the nation's readiness in preparing generations is reported by PISA. This report described the children's reading, math, and science literacy. By literacy, they do not only know about the facts, concepts, principles, laws, and phenomena of science, but they are also able to apply this knowledge to solve problems in daily life. The literacy of 15-year-old of Indonesian children has not been encouraging yet and they are always below the average of OECD member countries. In 2012, Indonesia was placed at rank 64 of 65 countries, with scores below the OECD average score [2], and in 2015 was placed at rank 63 of 71 countries [3]. Meanwhile, they are the productive ages that will have a big role in determining the social, political and economic development of their nation, in the next 5 to 10 year.

If we examine it deeply, the fundamental issue is not the curriculum itself. This is because all curricula which have been applied in Indonesia use the same philosophical foundations and modern theories of education. The real issue lies in the policy and implementation of them in the classroom by practitioners and educators that have not met their objectives. This is a complex problem because the implementation of the curriculum is highly dependent on the adequacy of eight national education standards. Two of them are related to the quality of educators and educational staff and adequacy of facilities and infrastructure that generally still require improvement.

The K-13 is designed to complete the lack of previous curricula. It intends to (1) develop a balance between spiritual and social attitudes, knowledge and skills, and applying them in school and community situations, (2) place schools as part of a community that provides learning experiences so that learners are able to apply what they learn in school to society and utilizing the community as a source of learning, (3) allow sufficient time to develop various attitudes, knowledge, and skills, (4) develop Core Competencies as the organizing elements of Basic Competencies, and develop Basic Competencies based on accumulative principles, reinforced and enriched inter-subjects and educational levels (horizontal and vertical organizations), and (5) strengthen, deepen, expand of relevant content to learners and integrated content that is considered important in international comparison [1]. 
To achieve purposes of $\mathrm{K}-13$, the learning process is recommended using a scientific approach to encourage students to be more capable of observing, questioning, gathering information or data, associating and communicating concepts to others. This approach will lead to improve and balance between students' soft skills, hard skills, as well as knowledge. Therefore, various learning strategies have to be applied by teachers to develop students' high-order thinking skills such as critical thinking and creative thinking and also to cultivate the students' inquiry ability. The above facts illustrate that the K-13 has been emphasized learning process to achieve the learning objectives.

One of the determining factors of K-13 successful in class is the accuracy of the teacher's choice to learning strategy. Innovative process-based learning strategy has been developed by education experts. However, the selection of appropriate strategies is needed to fit the content analysis and students' characteristics. This paper analyzes the suitability of cognitive style-based learning strategy (CSBLS) [4] to support the implementation of webbed or integrated thematic curriculum in elementary schools. The CSBLS was developed to improve the weakness of the Problem-Based Learning (PBL) strategy as discussed later.

\section{THEORETICAL REVIEW}

\section{A. Cognitive Style Based Learning Strategy}

Cognitive style-based learning strategy was designed to overcome the weakness of PBL strategy. Even though PBL is able to train high-level thinking skills and problem-solving skills, this strategy is more suitable to higher education where students have a formal stage in cognitive development [5], [6]. Application of PBL on primary school students on concrete cognitive development does not show satisfactory results. In addition, the PBL strategy emphasizes the process, but less in the attainment of content knowledge [7], [8], [9]. Therefore, CSBLS is developed for students in the concrete cognitive development, taking into account students' cognitive style and strengthening their content knowledge. Students have different cognitive styles and can influence how to acquire and process information, their learning achievements and their problemsolving skills [10], [11], [12], [13]. Even though there is a tendency that FI students achieve learning outcome better than FD students, both FI and FD can be successful in learning as long as it is used the same strategy to their style [14].

The steps of learning strategy are based on the Gagne theory of learning events [15]. Gagne states that the learning process within a person is influenced by the external event of learning, which includes: attention, conveying learning objectives, stimulating recall of prerequisite knowledge, presenting learning, providing study guide, performing performance, giving feedback, assessing performance, and improving retention and knowledge transfer.

Expert assessment of the CSBLS shows that cognitive style-based learning strategy is feasible to be used in science learning. The learning strategy is valid, where the theories underlying this learning strategy is rational and logic. It means that learning strategy supported by the recent theories that are relevant to its characteristics (content validity). On the other hand, between the components of strategy have interrelated logically (construct validity) [4].

According to the field trials, the CSBLS is practical and effective to be used in elementary school classroom. Both teachers and students do not face significant obstacles in implementing this strategy in the classroom [16]. The implementation of this learning strategy can improve students' learning outcomes both conceptual understanding and process skills [17].

The CSBLS was designed based on the theory that the memory system is an active and organized information processor, and early knowledge plays an important role in learning (cognitive theory) [18], [19]. According to Bruner when students learn through discovery, they organize learning materials they learn with a final form which suits to their thinking level. Education is basically a process of personal discovery by each student [19]. In the learning process, students must construct knowledge (constructivism theory) through their interaction with objects, phenomena, experiences, and environment and constantly check new information toward previous rules and change them if they are not appropriate [20].

It is strongly recommended that CSBL is applied collaboratively to enable students to learn from their environment and develop their problem-solving abilities mediated by others (scaffolding). Scaffolding is a process of social interaction in the form of guidance from a more capable person in order for a person to reach their zone of proximal development [21].

Fully involvement and intensive learning interaction between students will produce meaningful learning. This condition will lead to processing information into long-term memory (LTM). It means that the real learning occurs. Someone is said to have learned when it has changed in its LTM. The information stored in LTM enables one to remember quickly and often unconscious and show what to do and when to do [22]. The process of LTM change according to information processing theory requires attention, right perception, rehearsal, full physical and mental engagement and the meaningfulness of learning activities.

Students learning outcomes, especially those related to cognitive domains such as conceptual understanding, process skills, and problem-solving skills are influenced cognitive style. Cognitive style is a consistent individual characteristic in processing information (perceiving, organizing, analyzing and solving problems) [23]. The cognitive style is not ability, but shows the way it processes information. Thus a person with different cognitive styles can be equally successful in learning if they learn using a method that suits their styles.

Students can be classified based on their cognitive style, namely Field Independent (FI) and Field Dependent (FD) cognitive style. Both groups have different preferences in processing information. The FI students have the characteristics (1) analytical, competitive, independent, and individual (2) have goals, objectives, strategies, and selfreinforcement (3) intrinsically motivated (4) lack of social 
skills/prefer individual tasks (5) structured and organized in learning. They are able to abstract elements or backgrounds from its context. They tend to use the problem-solving approach in a way that is more analytic. While students with FD cognitive style has the opposite characteristics [23].

The CSBLS have the steps which are abbreviate by word @UnESa-Gain. The @ or at= attention, Un = Understanding, $\mathrm{E}=$ Exploration, $\mathrm{Sa}=$ Sharing, $\mathrm{G}=$ Game, $\mathrm{A}=$ Assesment and In = Individual Task [4]. The CSBLS steps are described in Table 1.

TABLE 1. THE STEPS OF COGNITIVE STYLE BASED LEARNING STRATEGY

\begin{tabular}{|c|c|c|c|}
\hline No & $\begin{array}{l}\text { Learning } \\
\text { Steps }\end{array}$ & Learning Activities & Objectives \\
\hline 1 & Attention & $\begin{array}{l}\text { Teacher attracts the } \\
\text { students' attention to } \\
\text { learning through delivery } \\
\text { of learning objectives, } \\
\text { apperception, remind } \\
\text { and reinforce the } \\
\text { prerequisite knowledge }\end{array}$ & $\begin{array}{l}\text { - to prepare students } \\
\text { physically and } \\
\text { mentally to learn } \\
\text { - to ensure that students } \\
\text { have prior knowledge }\end{array}$ \\
\hline 2 & $\begin{array}{l}\text { Understandi } \\
\text { ng Problem }\end{array}$ & $\begin{array}{l}\text { Teacher conveys a } \\
\text { problem and ask groups } \\
\text { to understand the } \\
\text { problem and instructions } \\
\text { on the worksheet }\end{array}$ & $\begin{array}{l}\text { - to train the students' } \\
\text { ability to analyze } \\
\text { information, identify } \\
\text { and formulate the } \\
\text { problems (FI) }\end{array}$ \\
\hline 3 & Exploration & $\begin{array}{l}\text { The teacher encourages } \\
\text { and helps students to } \\
\text { gather the appropriate } \\
\text { information, conduct the } \\
\text { simple experiment or } \\
\text { observation to solve the } \\
\text { problem. } \\
\text { Students are encouraged } \\
\text { and guided by the } \\
\text { teacher to: } \\
\text { - formulate hypothesis } \\
\text { or prediction } \\
\text { - seek information from } \\
\text { various sources or } \\
\text { perform observation } \\
\text { to gather data } \\
\text { - interpret data } \\
\text { - draw conclusion } \\
\text { - evaluate the solution }\end{array}$ & $\begin{array}{l}\text { to train students to } \\
\text { solve problems by } \\
\text { applying process } \\
\text { skills and } \\
\text { collaboration (FI \& } \\
\text { FD) }\end{array}$ \\
\hline 4 & Sharing & $\begin{array}{l}\text { Teacher becomes } \\
\text { moderator in sharing } \\
\text { of ideas between } \\
\text { groups and provide } \\
\text { feedback } \\
\text { Students share their } \\
\text { ideas between groups } \\
\text { about the problem- } \\
\text { solving results }\end{array}$ & $\begin{array}{l}\text { to train students to } \\
\text { communicate the } \\
\text { solution of the } \\
\text { problem ( FD ) }\end{array}$ \\
\hline
\end{tabular}

TABLE 1. cont.

\begin{tabular}{|c|c|c|c|}
\hline 5 & Game & $\begin{array}{l}\text { - The teacher invites } \\
\text { students to play } \\
\text { rehearsal game in } \\
\text { order to deepen and } \\
\text { strengthen the content } \\
\text { knowledge } \\
\text { - Students play the } \\
\text { rehearsal game } \\
\text { - The throwing ball } \\
\text { game: Ball that } \\
\text { contains the questions } \\
\text { of key concepts } \\
\text { thrown from one } \\
\text { student to another } \\
\text { (accompanied by } \\
\text { singing). Students } \\
\text { who get the ball as the } \\
\text { singing was stopped } \\
\text { must answer the } \\
\text { question }\end{array}$ & $\begin{array}{l}\text { - to deepen and } \\
\text { strengthen retention of } \\
\text { content knowledge } \\
\text { with enjoyable (FI \& } \\
\text { FD) }\end{array}$ \\
\hline 6 & Assessment & $\begin{array}{l}\text { - Teacher evaluates } \\
\text { both knowledge and } \\
\text { problem-solving } \\
\text { ability } \\
\text { - Students take the test }\end{array}$ & $\begin{array}{l}\text { - } \text { to measure conceptual } \\
\text { understanding, } \\
\text { problem-solving } \\
\text { ability and motivate } \\
\text { the students for } \\
\text { learning (FI) }\end{array}$ \\
\hline 7 & $\begin{array}{c}\text { Individual } \\
\text { Task }\end{array}$ & $\begin{array}{l}\text { The teacher gives the } \\
\text { individual task of } \\
\text { problem-solving as } \\
\text { learning enrichment } \\
\text { - Students solve the } \\
\text { problems individually } \\
\text { as the homework }\end{array}$ & $\begin{array}{l}\text { to strengthen the } \\
\text { problem-solving } \\
\text { ability and facilitate } \\
\text { the transfer of } \\
\text { knowledge (FI) }\end{array}$ \\
\hline
\end{tabular}

\section{B. Learning Science in Elementary School}

According to Piaget, elementary students (6-11 years old) are placed to the concrete operational stage of cognitive development [20]. Ref. [24] reported that generally, the elementary school students of Banjarmasin have the concrete cognitive development and few of them have transition and beginning of formal reasoning. Meanwhile, the most of them have the field-dependent cognitive style.

Elementary students begin to develop their ability to think logically and build social relationships with others [25]. They are rooted deeply in their environment and have difficulty with abstract thinking. They are able to construct concepts to see relationships and even to solve problems if they involve a real object or known situation. They tend to show the holistic perception of the world. In addition, they have evolved the ability from egocentric thinking to objective thinking. This situation allows them to see that someone else may have a different perception. It is to be provided in social interaction within their community

According to the K-13, learning in elementary school has to implement a webbed or integrated thematic curriculum, although, the disciplined approach of learning is simpler than the interdisciplinary one. The former is not in line with students' cognitive development stage described above, multiple intelligence theory and brain-based learning theory.

According to Gardner, human intelligence is the ability to create and solve the problems [26]. Based on the understanding that the intelligence profile of each individual is 
not the same, so learning can be developed to evaluate the students' intelligence profiles and to design learning activities based on the students' intelligence level. So, interdisciplinary integrated learning will be more facilitate the uniqueness and diversity of students' intelligence.

Learning will be enhanced if the learning creates environments that facilitate our brain work optimally and enhanced learning [27]. Application of integrated thematic curriculum can create a learning environment that will encourage the brain work optimally: (1) create a challenging atmosphere through diversity activities or enriched environment, (2) able to present information that not only focus but also peripheral information, (3) facilitate information processing not only partially but also comprehensively, (4) create learning that multifaceted, with inherent choices and options for learner with the unique of brain, (5) create learning where facts embed in natural, spatial memory, (6) create learning invoke integrated learning, thematically reflective approaches, learning is more branding compatible, subsequently, and enhanced, and (7) creating learning that organized experientially and reflectively to benefit maximally from the deep processing.

Webbed model is very appropriate to be applied in elementary schools since most of the students tend to see everything as a whole (holistic), their physical development cannot be separated from the development of mental, social, and emotional. This model provides breadth and depth of implementation, offers the opportunity to the students to bring a lot of dynamics in education. The thematic unit is the epitome of the whole subject matter that facilitates students to learn productively in order to answer their self-questions and satisfy their curiosity about the world around them.

Stanciak and Doll [28] state that thematic approach has five characteristics (1) learning content related to student life, so that students show a natural interest and have the intrinsic motivation (Relevance), (2) learning unit displays problematic situations that allow students to learn in a multidimensional or use various intelligence and express what is known or what is being studied (Richness), (3) between one discipline to another discipline related by theme, for example between mathematics and science (Relatedness), (4) learning should be challenging and teaching students to apply higher order thinking such as problem solving, process skills, decision making consciously, and creative ideas (Rigor), and (5) the theme is said to have properties recursivness if it is encountered both in school and in daily life. The theme gives opportunities to the student for transferring skills and concepts to the new situations (Recursive).

Implementation of a webbed or integrated thematic model in National Curriculum 2013 uses a scientific approach, where learning process has to train some skills includes observing, questioning, associating, experimenting, and networking/communicating [1] as illustrated in Figure 1. By this approach, students' scientific processes and scientific attitude will be developed.

\section{1) Observing}

Observing is an early activity in learning to arouse students' curiosity. The objective is to collect information by using with all senses or with appropriate equipment. The forms of observing activities include reading, listening, viewing videos, observing demonstrations and observing the surrounding environment that is relevant to the underlying competencies being studied.

Teachers need to apply appropriate strategies so that students develop their observing skills. Strategies to train observing skills include showing phenomena of natural, social or object-specific, giving the opportunity to students to observe, guiding students to focus on observing objects in accordance with learning objectives, encouraging students to describe their observation data and giving strengthening [29].

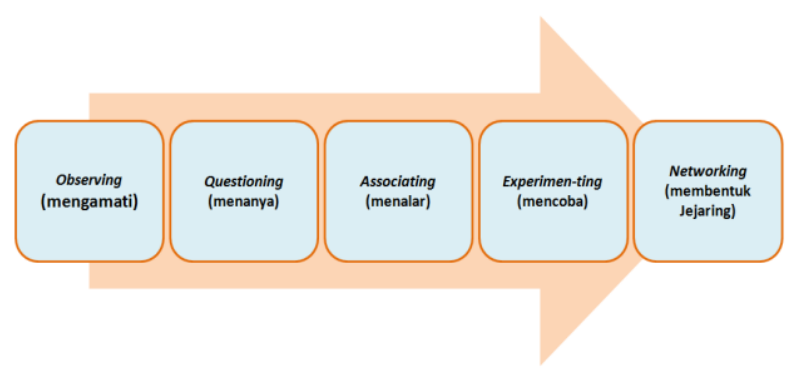

Fig 1. Scientific Approach

\section{2) Questioning}

Questions that arise after observing is a form of want to know based on factual knowledge obtained. Thus, the observing and questioning activity is a sequential activity. The question posed by students is not a question of getting answers from the teacher. Good questions should be relevant to the observation results, indicating the relationship of variables or categorization and can be tested through investigation activities to find the answer. Questions that lead to the investigation as "what is the problem?", What will happen if ... ..? "," What are the causes......? ". The role of the teacher is not to answer students' questions, but to facilitate students to find answers or solutions.

Strategies that can be applied to train students' questioning skills as encourage students to ask based on observations through teacher's quitting questions, allow sufficient time for students to ask questions, provide a positive response to students who are actively questioning and show inquiry questions, write down student questions as a problem formulations to be investigated and provide reinforcement of the questions asked by the students [29].

\section{3) Experimenting}

Experimenting is a student activity to explore and elaborate information based on the problem formulations. Information-gathering activities can include literature reading, watching videos, interviewing, experimenting, field observation, and practicing specific activities in accordance with learning objectives. Students have experimenting skills if they are able to explain the design or procedure of experimenting or exploring information, the variables that need to be recorded and applying them in accordance with the procedure. 
Strategies that can be applied to train students' ability to question as showing students how to use the tools/materials/objects, facilitating the tools/materials that are needed, guiding students to observe their experiments, guiding students in recording data, guiding students to process data into information [29].

\section{4) Associating}

The associating refers to connections between conceptual or mental entities as a result of the similarity between thought or closeness in space and time [1]. Associating is a cognitive activity of students in building knowledge. Through associating activities, students connect between factual information that has been collected in a trying activity, to form conceptual knowledge. Associating activities such as classifying data are based on certain characteristics and describing the causal relationships between treatments and observed facts. This conceptual knowledge is the conclusion or solution to the problem formulations being investigated. Strategies that can be done to train reasoning skills include guiding students to make categorization and guiding students to make associations or causal relationships.

\section{5) Networking/Communicating}

Communicating is a student activity to convey and provide an explanation of the facts and conclusions to others. This communicating activity can be done either in writing or verbally or both of them. Communicating is part of networking activities, building relationships with others in order to share and consolidate the knowledge that is constructed. This activity is also able to facilitate students to develop social skills.

Strategies to train communicating skills as guiding students to write the results of his investigation, facilitating students to present the results of investigations with appropriate media, giving students the opportunity to deliver written reports orally in front of the class or in the form of poster exhibition.

Learning by using scientific approach is designed in a collaborative situation so that students can achieve social skills as nurturance effects of learning such as collaboration, empathy, mutual respect, and acceptance of differences. Even though the task is done in groups, it suggests that the results of observation and discussion should be conducted by each student. So, each student also has a personal responsibility other than shared responsibility.

The scientific approach trains students' process skills and uses scientific methods to solve their daily problems. Scientific approach encouragement and inspire students to think critically and analytically in identifying, understanding, problem-solving, and applying concepts. So, the scientific approach will be achieving three domains of learning outcome comprising attitude (know why), psychomotor skills (know how) and knowledge (know what).

\section{DISCUSSION}

The big ideas of implementation K-13 at the primary school is applying integrated thematic curriculum model at all grade levels and prioritizing scientific approach in the learning process. K-13 also changed the fundamental paradigm in learning that is to encourage students' involvement by changing the focus of knowledge achievement to comprehensive achievement learning outcome covering attitude, knowledge, and skill.

The application of K-13 encourages teachers to be more creative in designing and developing learning. Although, the Ministry of Education and Culture has provided all the learning materials such as syllabus, teacher's book, and students' book, however, the teacher should design the learning according to the condition of their student based on content and student analysis. One of them is chosen as a strategy that will be applied in learning.

There is no single strategy to teach all kinds of knowledge (factual, conceptual, procedural, and metacognitive). Each strategy or learning model is generally designed for a specific purpose. Therefore, the application of multi-strategy or multimodel is a necessity.

The CSBLS is designed for classroom learning that involves factual, procedural and conceptual knowledge. This strategy was developed based on the constructivist theory that prioritizes science process skills. The developed process skills include observing skills, making predictions, interpreting abilities, concluding abilities and communicating abilities. This strategy is proved to be able to increase the students' conceptual understanding and students' process skills significantly [17].

Based on the learning activities developed through the learning stages, the CSBLS is aligned with the activities developed through a scientific approach in K-13. All the skills have to be equipped to students, observing, questioning, experimenting, associating, communicating, presented by the CSBLS. Even, CSBLS also combine between social and individual skills and responsibility through collaboration and individual task, respectively. The conformity of CSBLS activities to activities of the scientific approach is presented in Table 2.

TABLE 2. CONFORMITY CSBLS TO SCIENTIFIC APPROACH ACTIVITIES

\begin{tabular}{|c|c|c|c|}
\hline No & $\begin{array}{c}\text { Scientific } \\
\text { Approach }\end{array}$ & $\begin{array}{c}\text { Learning Activities of } \\
\text { CSBLS }\end{array}$ & CSBLS Steps \\
\hline 1 & Observing & $\begin{array}{c}\text { Teacher attracts the } \\
\text { students' attention to } \\
\text { learning through delivery } \\
\text { of learning objectives, } \\
\text { apperception, remind and } \\
\text { reinforce the prerequisite } \\
\text { knowledge }\end{array}$ & Attention \\
\hline 2 & Questioning & $\begin{array}{c}\text { Teacher conveys a } \\
\text { problem and asks groups } \\
\text { to understand the } \\
\text { problem and instructions } \\
\text { on the worksheet }\end{array}$ & $\begin{array}{c}\text { Understanding } \\
\text { problem }\end{array}$ \\
\hline
\end{tabular}


TABLE 2, cont.

\begin{tabular}{|c|c|c|c|}
\hline 3 & $\begin{array}{l}\text { Experimenting } \\
\text { and Associating }\end{array}$ & $\begin{array}{l}\text { Teacher encourages and } \\
\text { helps students to gather } \\
\text { the appropriate } \\
\text { information, conduct the } \\
\text { simple experiment or } \\
\text { observation to solve the } \\
\text { problem. } \\
\text { Students are encouraged } \\
\text { and guided by the } \\
\text { teacher to: } \\
\text { - formulate hypothesis } \\
\text { or prediction } \\
\text { - seek information from } \\
\text { various sources or } \\
\text { perform observation to } \\
\text { gather data } \\
\text { - interpret data } \\
\text { - draw conclusion } \\
\text { - evaluate the solution }\end{array}$ & Exploration \\
\hline 4 & Communicating & $\begin{array}{l}\text { Teacher becomes } \\
\text { moderator in sharing } \\
\text { of ideas between } \\
\text { groups and provide } \\
\text { feedback } \\
\text { - Students share their } \\
\text { ideas between groups } \\
\text { about the problem- } \\
\text { solving results } \\
\end{array}$ & Sharing \\
\hline
\end{tabular}

The CSBLS trains various cognitive competencies in the form of knowledge, process skills, and problem-solving skills as an instructional effect. In addition, it also facilitates students to develop affective domain (social skills and character) and psychomotor skills as nurturance effect. Both groups of learning objectives domain are gradually developed through adequate scaffolding until students reach the selflearning.

Combines of individual learning and learning in a social context, this strategy is based on students' cognitive style differences, FI and FD. The learning steps are designed to accommodate both types of students in the classroom. As an example is exploration stage. This step involves much more analytical and reasoning activities that are more suitable for FI students. Meanwhile, collaborative learning is applied here in order to give the opportunity to students to interact with among others. It will accommodate the character of FD group students. With such a design, it is expected that all students can achieve learning competences optimally. The results show that both groups of students can achieve good cognitive competence, attitudes, and skills in learning. FI students tend to achieve better of the cognitive learning outcomes than FD students, although not all learning contents [17]. This fact proves that CSBLS can facilitate both groups of students.

Implementation of the CSBLS in an integrated thematic curriculum in elementary school only requires adaptation in relation to theme-based learning materials only. CSBLS is appropriate to apply in the context of integrated curriculum since this basic of strategy is an authentic problem-solving activity. The authentic problem solving through interdisciplinary approach is resonating with integrated thematic curriculum.
The CSBLS is one of the inquiries strategies that has been developed in the education field. The implementation of inquiry learning strategies has to consider students readiness in relation to their knowledge, experience, and skills [30]. Students with a lack of knowledge, experience, and skills, need more guidance or scaffolding to success in inquiry activities. Basically, elementary school students can form the concepts, see the relationships and solve the problems as far as involving objects and situations already known [19], [20], [25]. This inquiry should be implemented in a contextual and funny issues background.

Scaffolding aims to make the learning can be followed by students because they reach their zone of proximal development. Scaffolding realizes in the variety of activities such training, structuring tasks, simplifying tasks and giving cues but does not provide the final answer to the tasks. Scaffolding also serves to direct the students' attention to the important learning goal. Thus scaffolding not only helps the students how to do the work but also why the task must be done in a certain way and whether learning has achieved its objectives.

\section{CONCLUSION}

Along with the enactment of K-13 in Indonesia, there is a change in the implementation of the curriculum model at the elementary school level. In the Education Unit Level Curriculum 2006, grades 1, 2 and 3 of elementary school apply a webbed or thematic curriculum model, while grades 4, 5 and 6 apply subject-based curriculum. At K-13 all grade levels of elementary school have to apply an integrated thematic curriculum model.

The webbed or integrated thematic curriculum incorporates various disciplines to achieve cognitive, affective, and psychomotor competencies. The suggested learning approach is the scientific approach, which involves four main skills namely observing, questioning, experimenting, associating, and networking/communicating.

Cognitive Style-Based Learning Strategy has the steps that are in line with a scientific approach. The steps are concise of Attention, Understanding, Exploration, Sharing, Game, Assessment, and Individual Tasks. Understanding step more trained skill of questioning, Exploration step more trained skills of observing, associating, communicating data, Sharing step trained a verbal communicating and Individual Tasks involves all skills which are undertaken independently by students.

According to the characteristics, the Cognitive Style-Based Learning Strategy can be applied in K-13, only requires the change of learning materials from subject areas to themes as a learning content. Implementation of the learning strategy can facilitate individual differences especially related to elementary students' cognitive style and their tendency to prefer group activities. 


\section{REFERENCES}

[1] I. Sunardi, Sujadi, E. W. Winarni and Suryanti, Kompetensi Pedagogik, Jakarta: Kementerian Pendidikan Dan Kebudayaan Direktorat Jenderal Guru Dan Tenaga Kependidikan, 2017.

[2] OECD, "PISA 2012 Results in focus what 15-Year-olds know and what they can do with what they know", www.oecd.org/pisa/keyfindings/ Pisa-2012, Accessed on 2 Pebruari 2014.

[3] OECD, "PISA result in focus", www.oecd.org/, 2016.

[4] A.Sholahuddin, L.Yuanita, and S.Kardi, @UnESa-GAIn learning strategy for developing the science problem solving ability of elementary school students, Proceeding International Conference on Education Research and Innovation (ICERI), 2014, pp. 407-415.

[5] R. I. Arends, Learning to Teach ( $7^{\text {th }}$ Ed.), (H. P. Soetjipto \& S. Mulyantini, Trans.) Yogyakarta: Pustaka Pelajar, 2008.

[6] C. E. Hmelo-Silver, and H. S. Barrow, "Goals and strategies of a problem-based learning facilitator", The Interdisciplinary Journal of Problem-Based Learning, vol. 1, no. 1, pp. 21-39, 2006.

[7] K. N. Drake and D. Long, "Rebecca's in the dark: A comparative problem-based learning and direct instruction/experiential learning in two $4^{\text {th }}$-grade classrooms", Journal of Elementary Science Education, vol. 21, no. 1, pp.1-16, 2009.

[8] S. Burris and B. L. Garton, "Effect of instructional strategy on critical thinking and content knowledge: Using problem-based learning in the secondary classroom", Journal of Agricultural Education, vol. 48, no. 1, 2007, pp. $106-116$.

[9] W. J. Stepien, S. A. Gallagher, and D. Workman, "Problem-based learning for traditional and interdisciplinary classrooms", Journal for the Education of the Gifted, vol. 16, no. 4, pp. 338-357, 1993.

[10] T. G. Ratumanan, "Pengaruh strategi pembelajaran dan gaya kognitif terhadap hasil belajar matematika siswa SLTP di Kota Ambon", Jurnal Pendidikan Dasar, vol. 5, no. 1, pp. 1 - 10, 2003.

[11] I.M. Ardana, "Peningkatan kualitas belajar siswa melalui pengembangan pembelajaran matematika berorientasi gaya kognitif dan berwawasan konstruktivis", Jurnal Penelitian dan Pengembangan Pendidikan, vol.1, no. 1, pp. 1-14, 2008.

[12] D. Stamovlasis, G. Tsitsipis, and G. Papagergeou, "The effect of logical thinking and two cognitive styles on understanding the structure of matter: an analysis with the random walk method", Chem. Educ. Res. Prac, vol.11, pp. 173-181, 2010,

[13] C. Tinajero, and M. F. Paramo, "Field dependence-independence and academic achievement: A re-examination of their relationship", British Journal of Educational Psychology, vol. 67, no. 2, pp. 199-212, 1997.

[14] R. Dunn and K. Dunn, Teaching Secondary Students through Their Individual Learning Styles, Practical Approaches for Grades 7-12, Boston: Allyn and Bacon, pp. 1-29, 1993.

[15] R. M. Gagne, L. J. Briggs, and W. W. Wager, Principle of instructional design, Fort Worth: Harcourt Barace Jovanovich College Publishers, 1992.

[16] A. Sholahuddin, L. Yuanita, and S. Kardi, Practicality of cognitive stylebased learning strategy for developing science problem-solving ability of elementary students, Proceeding of $3^{\text {rd }}$ International Conference on Research, Implementation and Education of Mathematics and Science, (ICRIEM), pp. 17-24, 2016.

[17] A. Sholahuddin, and L. Yuanita, Effect of cognitive style-based learning strategy to students' conceptual understanding of science process skills, Proceeding International Conference on Education Research and Innovation (ICERI), pp. 500-507, 2017.

[18] D. A. Jacobsen, P. Eggen, and D. Kauchak, Methods for Teaching. ( $8^{\text {th }}$ Ed.), (A. Fawaid dan K. Anam, Trans.), Yogyakarta, Indonesia: Pustaka Pelajar, 2012.

[19] Suyono dan Hariyanto, Belajar dan Pembelajaran: Teori dan Konsep Dasar [Teaching and learning: Theories and basic concepts), Bandung, Indonesia: P.T Remaja Rosda Karya, 2011.

[20] R. I. Slavin, Education Psychology ( $9^{\text {th }}$ ed.), New Jersey, NJ: Pearson, 2009.

[21] R. L. Solso, O. H. Maclin, and M. K. Maclin, Cognitive Psychology. ( $8^{\text {th }}$ Ed.), New York, NY: Pearson, 2008.
[22] P. A. Kirschner, J. Sweller, and R. E. Clark, Why minimal guidance during instruction does not work: an analysis of constructivist, discovery, problem-based, experiential, and inquiry-based teaching. Educational Psychologist, 41(2), 75-86, 2006.

[23] G. A. Davis, Learning style and personality type preferences of community development extension educators, Journal of Agricultural Education, vol. 47, no. 1, pp. 90-99, 2006.

[24] A. Sholahuddin, dan S. W. Arsyad, Pembelajaran sains dan karakteristik siswa sekolah dasar kota Banjarmasin, Vidya Karya Jurnal Kependidikan, vol.27, no. 4, pp. 443-452, 2014

[25] K. A. Allen, dan L. R. Marotz, Profil Perkembangan Anak, Prakelahiran hingga Usia 12 tahun (Terjemahan oleh Valentino), Jakarta: PT Indeks, 2010 .

[26] H. Gardner, Multiple Intelligences The Theory in Practice, New York: Basic Book A Division of Harper Collins Publisher, 1993.

[27] R. Fogarty, How to Integrate the Curricula, California: A SAGE Company, 2009.

[28] R. Fogarty, Problem Base Learning and Other Curriculum Models For Multiple Intelligences Classroom, Illinois: IRI Skylight Training and Publishing, Inc., 1997.

[29] LPMP Kalsel, Model Pendampingan pada Sekolah Percontohan dalam Implementasi Permendikbud Nomor 103 dan 104 Tahun 2014 di Propinsi Kalimantan Selatan, Banjarbaru: LPMP Kalsel, 2015.

[30] A. Sholahuddin and Y. Shadriyah, Analysis of students' process skills and chemistry learning outcomes, The $5^{\text {th }}$ South East Asia Development Research Conference (SEA-DR) International Conference. (pp. 364370). Amsterdam: Atlantis Press, 2017, doi:10.2991/seadric-17.2017.79 